\title{
Growth trends reveal the forest structure during Roman and Medieval times in Western Europe: a comparison between archaeological and actual oak ring series (Quercus robur and Quercus petraea)
}

\author{
Kristof HANECA ${ }^{\text {a*}}$, Joris VAN ACKER ${ }^{\mathrm{a}}$, Hans BEECKMAN ${ }^{\mathrm{b}}$ \\ ${ }^{a}$ Ghent University, Department of Forest and Water Management, Laboratory of Wood Technology, Coupure Links 653, 9000 Gent, Belgium \\ ${ }^{\mathrm{b}}$ Royal Museum for Central Africa, Laboratory of Wood Biology and Xylarium, Leuvensesteenweg 13, 3080 Tervuren, Belgium
}

(Received 13 December 2004; accepted 23 May 2005)

\begin{abstract}
At some point in time, man has influenced nearly all forests in Western Europe. Most of the original forest cover has been converted to arable land and pastures, or has been cut for the supply of firewood and construction timber. In order to secure a sustainable source of firewood, the structure of the remaining forests was often altered. Especially coppice of European oak became increasingly popular during the Roman era and the Middle Ages. Ring-width series of oak trees from Roman times and Medieval settlements were recorded. In order to extract more detailed information regarding past forest structure and management, those series were compared to growth patterns of contemporary oak. The modern oaks were selected on forests sites in Flanders (northern Belgium) with well-known structure and management. Some remarkable similarities in growth patterns were observed. These findings yield tentative assumptions regarding past forest structure and management.
\end{abstract}

dendrochronology / growth trends / Quercus spp. / forest structure / coppice

\begin{abstract}
Résumé - Les tendances de croissance révèlent la structure des forêts en Europe Occidentale aux époques Romaines et Médiévales : comparaison entre séries d'accroissements annuels archéologiques et contemporains (Quercus robur et $Q$. petraea). Au cours de l'histoire, l'homme a influencé quasiment toutes les forêts en Europe. De grandes surfaces boisées ont été transformées en champs et pâtis ou ont été abattues pour récolter du bois de chauffage et de construction. Pour s'assurer d'une source durable de bois de chauffage, la structure des forêts restantes a souvent été adaptée. Surtout les bois de taillis de chêne sont devenus très populaires pendant la période romaine et au Moyen Âge. Des séries dendrochronologiques de chênes provenant d'établissements romains et médiévaux ont été analysées. Pour obtenir plus d'informations précises concernant la structure et la gestion des forêts antérieures, les séries ont été comparées avec celles de chênes contemporains. Ces chênes modernes ont été sélectionnés dans des forêts, avec des structures bien connues, situées en Flandres (Belgique). Quelques similarités remarquables observées dans les modèles de croissance ont permis de formuler des hypothèses concernant la structure et l'aménagement des forêts antérieures.
\end{abstract}

dendrochronologie / modèles de croissance / Quercus spp. / structure de la forêt / taillis

\section{INTRODUCTION}

In Europe, man, at some point in time, has influenced almost all forests and woodlands [9, 21, 26]. Already during Roman times the original vegetation in Western Europe was converted on a large scale. Forests were cleared and converted to arable land and pastures, or were cut for the supply of firewood and construction timber. During the Middle Ages, the remaining forests were further reduced in their dimensions. For instance, in Flanders (northern Belgium), it is estimated that the lowest forest cover ever was encountered as early as in the second half of the thirteenth century [26]. In order to secure a sustainable source for firewood, forests were often altered in structure.
Coppice, especially of European oak (Quercus robur L. and $Q$. petraea (Matt.) Liebl.), became one of the most popular and widely dispersed short rotation systems [1,21]. Coppiced oak trees regenerate fast [29] and provide small-dimension timber, and in addition the acorns were used as fodder for pig husbandry.

The reconstruction of past environments and biological communities has become an interesting topic for archaeobotanists, archaeologists and historians over the last few decades. For the reconstruction of past woodland and forest composition palynology, anthracology and the examination of macro remains are the most obvious proxies. Analyses of pollen grains, charcoal and fruits provide valuable information on the

* Corresponding author: Kristof.Haneca@UGent.be 
species composition and on changes in vegetation cover, but fail to provide detailed information on forest structure and dynamics.

Changes in the environmental conditions experienced by trees and shrubs trigger physiological processes that modulate the development of the secondary xylem, i.e. wood. Trees record such changes in their growth pattern $[11,25]$. Tree-ring width and series of ring-width measurements are therefore potential archives of changes in the local or global environment. Gradual or abrupt changes in ring width that occur simultaneously in many trees growing at the same environment are often related to changing growth conditions [12]. Silvicultural intervention is an example of a process that can modulate the growth-ring pattern of the majority of trees in the affected stand. Therefore growth patterns from large collections of wood specimens, found during archaeological excavations, on waterlogged sites and from architectural objects can be considered as suitable proxies for the reconstruction of past forest architecture $[6,32]$.

Most silvicultural interventions aim to modulate the growth rate of trees and hence influence the width of the tree-rings. For ring-porous species in general and European oak more specific, it has been demonstrated repeatedly that tree-ring width and cambial age (i.e. the number of the growth ring starting from the pith) highly determine the wood density. The latter variable is significantly related to the overall quality and the mechanical properties of the wood $[19,28]$. Fast grown oaks provide highdensity wood $\left(650-850 \mathrm{~kg} / \mathrm{m}^{3}\right)$, while low-density oak $(550-$ $\left.750 \mathrm{~kg} / \mathrm{m}^{3}\right)$ is often characterized by small rings [22]. Highdensity oak timber has better strength properties compared to low-density oak, while the latter has better physical characteristics and is more easily worked.

The question arises whether it is possible to distinguish between forest types based on a study of the ring-width patterns. It will be examined if characterization of the growth patterns from modern stands with well-known structure and management could help to reconstruct past forest structure from growth patterns of archaeological wood specimens. Moreover, the recorded ring-width series of modern, archaeological and historical trees will be compared with regard to wood quality. This could provide more information on the available wood assortments in a historical context.

\section{MATERIALS AND METHODS}

\subsection{Selected contemporary forest sites}

Fifteen contemporary forest sites in Flanders with well-known management and stand structure were selected for this study (Fig. 1 and Tab. I). Three main forest management systems can be distinguished: high forest, coppice and coppice-with-standards. Forest managed as high forest is focussed on the production of high-quality construction timber and logs for the veneer industry. Examples of such sites, with an abundance of European oak, are found southeast of Brussels in the Zoniën forest and at Buggenhout, in the Flemish region. From the Tervuren Xylarium oak specimens from these forests have been selected: 107 cross sections (Q. robur) from four different sites (Epeler, Groenendaal, Zevenster, Kwekerij) in the Zoniën forest and 49 from Buggenhout ( $Q$. petraea). The stem disks were always sawn as close as possible to the ground level to get the maximum number

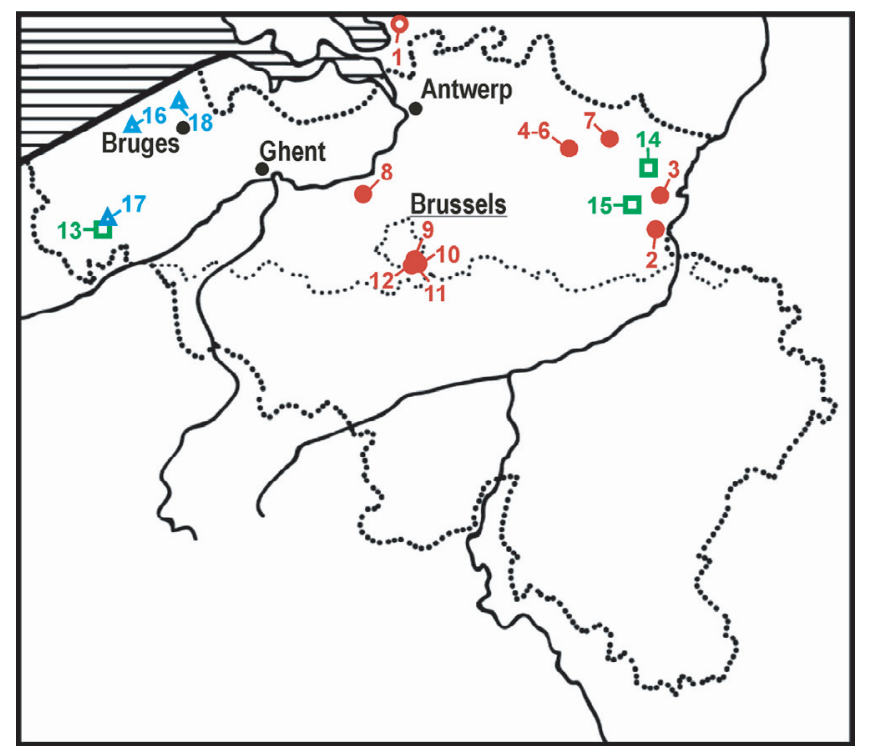

Figure 1. Location of the selected forest stands with well-known structure ( $\square$ coppice stands; $\bullet$ high forest; $\mathbf{0}$ oak under pine) and of the archaeological sites $(\triangle)$.

of rings, from stumps of recently felled trees. In six other high forests, on sandy soils in the north-eastern part of Belgium, two additional increment cores per tree were taken from four or five standing trees per site. On two other sites in the same area, both managed as a coppiced oak stand, increment cores were taken as well. Only one site (Kemmel), located in the south-western part of Flanders, was managed as coppice-with-standards. On this site increment cores from 17 trees were collected, i.e. increment cores from 12 coppiced trees and 5 widely spaced standards.

In addition, one forest site with natural regeneration of oak (Q. robur) under pine (Pinus sylvestris L. and Pinus pinaster Aiton) was selected as well. Within the 106 ha forest reserve Mattemburgh, in the municipality of Woensdrecht (The Netherlands) close to the Belgian border, increment cores of 97 naturally regenerated oak trees were collected.

\subsection{Archaeological and historical wood}

Wood samples were collected on two archaeological sites and from one historical building (Fig. 1). The archaeological excavation at Oudenburg, where remains of a Roman settlement were found, is located approximately $10 \mathrm{~km}$ east from the actual North Sea coast. Of particular interest were two well-preserved wooden water wells, both made of European oak. The water wells were probably constructed at the end of the 4th, beginning of the 5th century A.D. In total 22 cross sections from the logs were collected for tree-ring analysis.

From several archaeological excavations in the vicinity of the medieval town of Ypres (close to the French border) tree-ring patterns from approximately 250 wood specimens were analysed. The wooden $\log$ s were used as foundations for houses and revetments along a waterway and in a harbour. Dendrochronological research proved that the main building activity took place between A.D. 1250 and 1300 [14]. In total, 111 wood samples with pith and preserved sapwood were selected for this analysis.

A restoration project provided the opportunity to collect 33 crosssections from structural oak timbers of an impressive medieval storage house in Lissewege, ca. $10 \mathrm{~km}$ north of Bruges. Dendrochronological 
Table I. Description of the selected contemporary forest stands (a) and of the archaeological sites (b), with Quercus spp. (QUSP), Q. robur (QURO) and Q. petraea (QUPE).

(a) Contemporary forest stands

\begin{tabular}{lcccc}
\hline Nr. & Site & Species & Management system & No. of sampled trees \\
\hline 1 & Mattemburg & QURO & Natural regeneration under Pinus spp. & 97 \\
2 & Eisderbos & QUPE & High forest (natural regeneration) + regular thinning & 5 \\
3 & Kleine Homo & QURO & High forest (natural regeneration) + regular thinning & 5 \\
4 & Gemeentebos 12a & QURO & High forest (plantation) + regular thinning & 5 \\
5 & Gemeentebos 21a & QUPE & High forest (plantation) + regular thinning & 4 \\
6 & Gemeentebos 28a & QUPE & High forest (plantation) + regular thinning & 4 \\
7 & Pijnven & QUPE & High forest (plantation) + regular thinning & 5 \\
8 & Buggenhoutbos* & QUPE & High forest (plantation) + regular thinning & 49 \\
9 & Epeler* & QURO & High forest (plantation) + regular thinning & 20 \\
10 & Groenendaal* & QURO & High forest (plantation) + regular thinning & 45 \\
11 & Zevenster* & QURO & High forest (plantation) + regular thinning & 24 \\
12 & Kwekerij* & QURO & High forest (plantation) + regular thinning & $17(12+5)$ \\
13 & Kemmelberg & QURO & Coppice-with-standards & 5 \\
14 & Gruitrode* & QURO & Coppice & 10 \\
15 & Klaverberg & QUPE & Coppice &
\end{tabular}

(b) Archaeological sites

\begin{tabular}{lcccc}
\hline Nr. & Site & Species & Description & No. of samples \\
\hline 16 & $\begin{array}{c}\text { Oudenburg } \\
\text { (ca. 350-450 A.D.) }\end{array}$ & QUSP & Roman settlement with two well-preserved water wells, constructed \\
with wooden logs & \\
17 & $\begin{array}{c}\text { Ypres } \\
\text { (1250-1300 A.D. })\end{array}$ & QUSP & Wooden poles and boards from several medieval constructions & \\
18 & Lissewege & QUSP & Medieval storage house & 33 \\
& $(1365-1370$ A.D. $)$ & & & \\
\hline
\end{tabular}

The cross sections from locations marked with a * are part of the Xylarium of the Royal Museum for Central Africa (Tervuren, Belgium).

dating proved that the oaks were felled somewhere between A.D. 1365 and 1370 (Haneca, unpublished data).

\subsection{Data processing}

Tree-ring widths of the contemporary, archaeological and historical wood specimens were measured to the nearest $0.01 \mathrm{~mm}$ using a LINTAB measuring stage and the TSAP-Win acquisition and processing software [23]. The growth patterns of the collected stem disks were highly variable due to the irregular shape of the stem at ground level. They were measured along 4-8 radii, and averaged in order to reduce intra-tree variability [11].

\subsection{Statistical description of the ring-width series}

Several statistical parameters are useful to scrutinize ring-width series with special regard to stand characteristics and forest management. Average ring width is supposed to provide information on a number of environmental factors, e.g. stand density, soil fertility and soil texture, water capacity, etc. $[11,12]$. The standard deviation of a ring-width series is a measure for the variability in the radial growth rate, and may among others indicate the occurrence of sudden changes in radial growth rate, like growth releases due to canopy disturbances or pollarding effects [24]. Oaks are known to exhibit a pronounced growth or age trends. Such trends could be related to the structure of the forest and can be partly quantified by first-order autocorrelation which is the correlation of each value in a time series with the value of its direct predecessor. The mean sensitivity $(\bar{S}$; Eq. (1)) is a measure of the variation in ring width from year to year [11], and theoretically ranges from 0 (no difference between adjacent years) to 2 (requires a ring width measurement of "zero"). Low values will represent series with more or less constant ring widths

$$
\bar{S}=\frac{1}{n-1} \sum_{i=1}^{n-1} \frac{\left|x_{i+1}-x_{i}\right| \times 2}{\left(x_{i+1}-x_{i}\right)} .
$$

\subsection{Growth trends}

Ring-width series have an annual resolution, what means that each growth ring can be assigned to a specific calendar year. Moreover, general trends in tree-ring series; e.g. the age trend, as well as the treering pattern in segments of different cambial age can be considered and might be more relevant regarding forest dynamics and development. For instance, tree-rings close to the pith are supposed to bear 
Table II. Descriptive statistics of tree-ring series from different contemporary stands with well-known structure, with Quercus spp. (QUSP), Q. robur (QURO) and Q. petraea (QUPE). AV. No. TR, AV. RW and AV. STDEV: the average number of tree rings, the average ring width and the average standard deviation of the tree-ring series. MS and $\mathrm{AC}(1)$ : the means sensitivity and the average first-order autocorrelation of the tree-ring series. AV. RW (20) and AV. STDEV (20): the average ring width and average standard deviation of the first 20 years of growth.

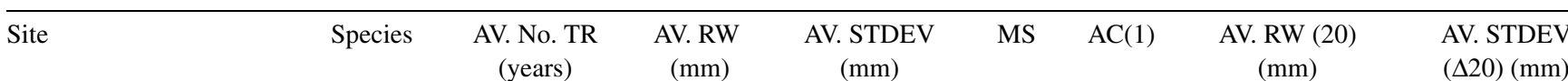

Natural regeneration of oak under canopy

Mattemburs

QURO

60.8

1.64

0.98

0.37

0.69

2.04

0.83

High forest (natural regeneration) + regular thinning

$\begin{array}{lccccccrr}\text { Eisderbos } & \text { QUPE } & 21.6 & 2.54 & 0.80 & 0.22 & 0.62 & 2.50 & 0.75 \\ \text { Kleine Homo } & \text { QURO } & 73.0 & 2.07 & 0.80 & 0.22 & 0.69 & 2.72 & 0.93 \\ \text { HF-nat. reg. (all) } & - & 40.2 & 2.47 & 0.83 & - & - & 2.61 & 0.84\end{array}$

High forest (plantation) + regular thinning

\begin{tabular}{|c|c|c|c|c|c|c|c|c|}
\hline Buggenhout & QUPE & 116.3 & 2.79 & 1.56 & 0.28 & 0.91 & 2.34 & 1.21 \\
\hline Epeler & QURO & 88.1 & 3.39 & 1.57 & 0.26 & 0.76 & 2.63 & 1.28 \\
\hline Groenendaal & QURO & 83.9 & 3.01 & 1.31 & 0.23 & 0.76 & 3.55 & 1.26 \\
\hline Zevenster & QURO & 87.2 & 2.42 & 1.39 & 0.26 & 0.79 & 3.12 & 1.25 \\
\hline Kwekerij & QURO & 134.5 & 3.22 & 1.30 & 0.28 & 0.67 & 2.53 & 0.94 \\
\hline Gemeentebos 12a & QURO & 72.6 & 1.89 & 0.78 & 0.23 & 0.72 & 1.59 & 0.69 \\
\hline Gemeentebos 21a & QUPE & 73.0 & 2.00 & 0.78 & 0.25 & 0.63 & 1.74 & 0.74 \\
\hline Gemeentebos 28a & QUPE & 64.5 & 2.06 & 0.89 & 0.26 & 0.71 & 2.36 & 0.84 \\
\hline Pijnven & QUPE & 84.0 & 1.65 & 0.84 & 0.25 & 0.73 & 2.54 & 0.85 \\
\hline HF-plant. (all) & - & 100.3 & 2.75 & 1.38 & - & - & 2.71 & 1.15 \\
\hline \multicolumn{9}{|l|}{ Coppice } \\
\hline Kemmel & QURO & 72.1 & 1.97 & 1.16 & 0.27 & 0.74 & 2.84 & 1.22 \\
\hline Gruitrode & QURO & 66.0 & 1.14 & 0.93 & 0.22 & 0.79 & 2.07 & 1.17 \\
\hline Klaverberg & QUPE & 56.0 & 2.33 & 0.87 & 0.21 & 0.55 & 2.59 & 0.84 \\
\hline Coppice (all) & - & 65.0 & 1.95 & 1.01 & - & - & 2.60 & 1.07 \\
\hline \multicolumn{9}{|l|}{ Standards } \\
\hline Kemmel & QURO & 75.6 & 2.61 & 1.34 & 0.226 & 0.77 & 3.64 & 1.48 \\
\hline
\end{tabular}

more information on (i) the light conditions at the time of regeneration as well as (ii) the type of regeneration. It is expected that regeneration from a stool, as is the case for coppiced trees, will result in a higher radial growth rate during the first years of growth compared to regeneration from acorns, because the shoots can profit from a fully developed root system.

More commonly used in forestry is the basal area increment (BAI) instead of the ring width. The basal area is defined as the area of the cross-section of a tree stem near the base, generally measured at breast height. The BAI is then defined as the increase in basal area of a tree over a specified time period (e.g. one growing season). Ring-width series can be converted to annual basal area increments (BAI $\mathrm{I}_{i}$; Eq. (2)) assuming that the growth rings form concentric circles. Such a conversion of ring-width series into annual BAI's helps to remove variation in radial growth attributed to an increasing circumference.

$$
B A I_{i}=\pi \times\left(R_{i}^{2}-R_{i-1}^{2}\right)
$$

with $\mathrm{BAI}_{\mathrm{i}}$ : basal area increment over year $i$; $\mathrm{R}_{\mathrm{i}}$ : sum of all ring widths, from the pith up to the growth ring with a cambial age of $i$ years, what equals the radius of the stem (without bark) at the end of the $i$-th growing season.

\section{RESULTS}

\subsection{Statistic descriptors of tree-ring series from contemporary forest sites}

Descriptive statistics of the tree-ring series from the contemporary forest management systems are listed in Table II. The youngest trees, mainly at the Eisderbos site, are 20 years old. Although these trees were cored at breast height, the number of recorded tree rings from the pith to the bark is considered to 
(a)

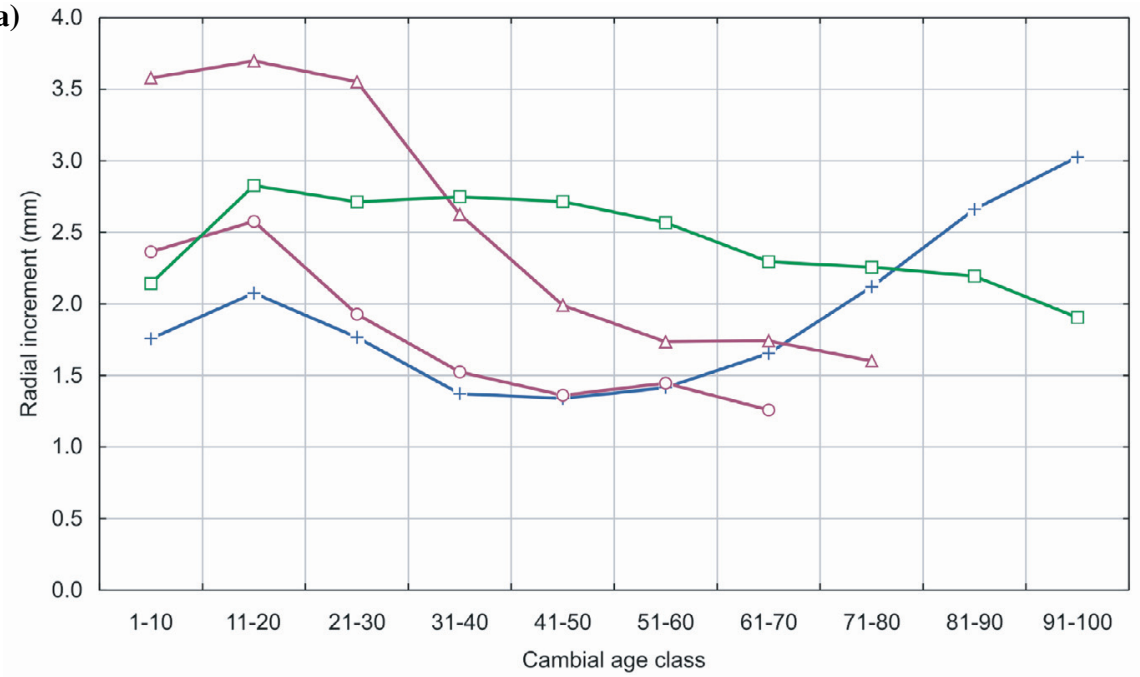

(b)

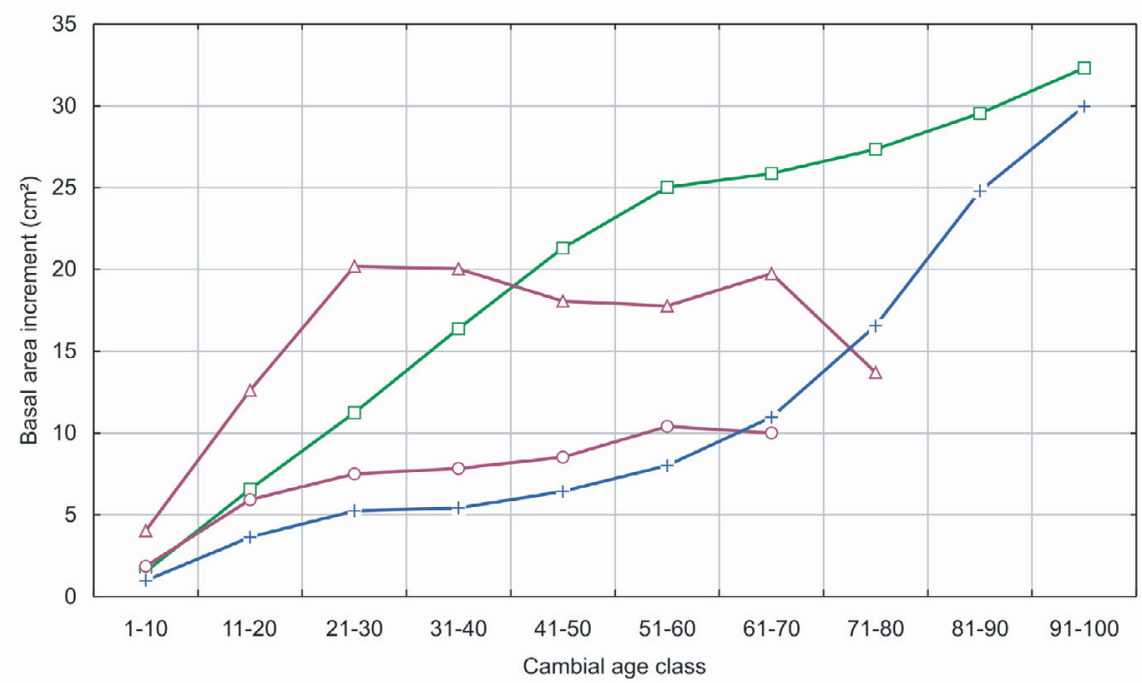

Figure 2. Average growth rate for cambial age classes of 10 successive years, starting from the pith: (a) radial increment $(\mathrm{mm})$, (b) basal area increment $\left(\mathrm{cm}^{2}\right)$. 0 coppice; $\triangle$ standards; $\square$ high forest; + natural regeneration of oak under pine. be a good approximation of the tree age. The oldest trees are about 135 years old and are found on the high forest sites in the Zoniën forest.

The average ring width is mostly higher in the intensively managed high forest stands, compared to stands managed as coppice or naturally regenerating oak trees under a close pine canopy (Mattemburg). The five sites with the highest growth rates (Buggenhout, Epeler, Groenendaal, Zevenster and Kwekerij) are all managed as high forest and are growing on fertile loamy soils with an adequate water capacity. Other high forest sites, on more sandy soils (Gemeentebos and Pijnven), display a more reduced growth rate. Significantly correlated with the average growth rate is the standard deviation $\left(r^{2}=\right.$ $0.687 ; p=0.001$ ).

The highest values of the first-order autocorrelation, AC(1), are found on the high forest plantations and coppice stands. According to these high values, these ring-width series are expected to display a conspicuous age-related trend. In general, oaks regenerated from acorns have a less pronounced age trend.

The mean sensitivity of the tree-ring series displays only little variation between the sites (Tab. II). Only on one site, the
Mattemburgh reserve, it peaks to 0.370 , what expresses a higher variation in ring width compared to trees from high forest and coppice stands.

\subsection{Description of the observed growth trends}

In order to retrieve information on the type of regeneration - from a stool, from seed or planted from a nursery - the average radial growth rate and its standard deviation were considered for the first 20 years of growth (Tab. II). For coppiced stands this average value is mostly higher than the overall growth rate. Stands that are managed as high forest display an opposite behaviour. Their average radial growth rate and standard deviation of the first 20 years is slightly lower than the overall growth rate.

Only when the average radial growth rate is computed for cambial age classes of 10 consecutive years, clear trends become visible. Particularly when for each management system all ring-width series with the same cambial age are averaged into one single series (Fig. 2a). Coppiced trees, i.e. trees regenerating from a stool, display the highest radial growth 
Table III. Descriptive statistics of tree-ring series from three archaeological sites in Flanders. N: number of tree-ring series. AV. No. TR, AV. RW and AV. STDEV: the average number of tree rings, the average ring width and the average standard deviation of the tree-ring series. MS and $\mathrm{AC}(1)$ : the means sensitivity and the average first-order autocorrelation of the tree-ring series. AV. RW (20) and AV. STDEV (20): the average ring width and average standard deviation of the first 20 years of growth.

\begin{tabular}{|c|c|c|c|c|c|c|c|c|}
\hline Site & $\mathrm{N}$ & $\begin{array}{l}\text { AV. No. TR } \\
\text { (years) }\end{array}$ & $\begin{array}{l}\text { AV. RW } \\
(\mathrm{mm})\end{array}$ & $\begin{array}{l}\text { AV. STDEV } \\
\quad(\mathrm{mm})\end{array}$ & MS & $\mathrm{AC}(1)$ & $\begin{array}{l}\text { AV. RW (20) } \\
(\mathrm{mm})\end{array}$ & $\begin{array}{l}\text { AV. STDEV } \\
(\Delta 20)(\mathrm{mm})\end{array}$ \\
\hline Oudenburg 1 & 8 & 38.4 & 3.35 & 1.37 & 0.23 & 0.73 & 3.99 & 1.31 \\
\hline Oudenburg 2 & 14 & 46.5 & 2.88 & 1.13 & 0.20 & 0.80 & 3.19 & 1.44 \\
\hline Ypres $(<50)$ & 54 & 31.6 & 2.38 & 0.83 & 0.22 & 0.60 & 2.63 & 1.19 \\
\hline Ypres $(>50)$ & 57 & 78.7 & 1.41 & 0.72 & 0.23 & 0.72 & 1.80 & 0.98 \\
\hline Lissewege $(<50)$ & 21 & 38.1 & 3.10 & 0.51 & 0.24 & 0.51 & 3.28 & 1.83 \\
\hline Lissewege (> 50) & 12 & 71.3 & 2.31 & 0.66 & 0.27 & 0.66 & 2.56 & 1.41 \\
\hline
\end{tabular}

rates in the first cambial age class (a cambial age of 1 to 10 years, starting from the pith). After they reached an age of ca. 20 years the growth rate rapidly decreases, and tends to stabilize at an age of 50-60 years. The widely spaced standards follow the same pattern, but the decrease in growth rate starts at least 10 years later. Oak trees in a high forest system display an increasing growth rate in the first 20-30 years, after which the growth rate steadily decreases. Naturally regenerating oak trees, which are shaded by pine trees in the Mattemburg reserve, also exhibit a rising growth rate over the first 10-20 years after germination. This trend is reversed after 20 to 30 years and starts to increase again at an age of about 50 to 60 , probably because of a less disadvantageous interference with the pines for light and nutrients.

Diverse growth trends are observed as well when BAI's are computed for the same cambial age classes (Fig. 2b). The high forest shows a constantly increasing growth trend over the first 100 years. For the first 50-60 years of growth the increase in BAI displays a constant and positive slope, which is then followed by a more moderate growth. The oak trees that regenerated under a close pine canopy also exhibit a constantly increasing growth trend but with a more gentle slope over the first 50-60 years compared to the high forest system. After 5060 years the slope of the BAI-curve starts to increase, similar to the trend observed for the radial increment. The BAI of the coppice trees behave slightly different, with a rapid increase in the first 10 to 20 years of growth, after which the BAI starts to rise at a more gentle pace. This trend is even more pronounced for the more widely spaced standards from a coppice-withstandards site. For these trees the BAI increases rapidly over the first 20-30 years of growth and then levels out or even starts to decrease.

\subsection{Statistic descriptors of tree-ring series from historical and archaeological sites}

A comparison of the descriptive statistics of the archaeological and historical wood specimens (Tab. III) with the tree-ring series from modern oak trees demonstrates that all values fall within the same range. For the tree-ring series from Ypres and Lissewege a striking difference in growth rate is observed when the series are divided arbitrarily in two groups according to their total number of rings. The shorter series (with less than 50 rings) exhibit a remarkably higher growth rate compared to the group with the longer tree-ring series. This is even more pronounced when only the first 20 years of growth are considered for both groups (Tab. III).

Ring-width patterns of wood specimens from the two archaeological sites and the medieval building were subjected to similar calculations as those of the contemporary trees (Figs. 3a, 3c and 3e). For archaeological wood specimens it is difficult to convert the ring-width series to BAI's since it is not possible to locate the sample compared to breast height $(1.3 \mathrm{~m})$. Nevertheless a conversion of the tree-ring widths by equation (2) will deliver satisfying results (Figs. 3b, 3d and 3f). They should be considered as an approximation of the actual BAI.

The tree-ring series from the excavation at Oudenburg were rather short, never exceeding a length of 75 years. The radialgrowth rates for the cambial age classes display a striking resemblance with the growth rates for contemporary trees from coppice stands (Fig. 3a). The high and increasing initial growth rate over the first 10-20 years is followed by a sudden decrease. When regarding the BAI's over the same cambial age classes, a pronounced increasing and nearly linear trend is obvious over the first 30 years of growth (Fig. 3b). This continuously rising trend is then halted and starts to decrease rapidly.

All tree-ring series from the excavations near Ypres were also aligned according to their cambial age. The radial growth rates did not display a clear trend similar to one of the contemporary forest management systems. Radial growth rates were then calculated separately for trees with less and more than 50 tree rings (Fig. 3b). It is apparent that the short tree-ring series exhibit a significantly higher radial growth rate than the longer series. The growth rate of the short series also decreases rapidly after ca. 20 years whereas the growth rate of the longer series only displays a gradual decrease. The general trend in BAI has a gentle and positive slope for both groups (Fig. 3c). Short series have, compared to the long series, a more rapidly increasing BAI over the first 10-20 years. Then the BAI stays nearly equal over the remaining growth period.

A similar procedure was applied to the tree-ring series from the medieval storage house at Lissewege. Again the average radial growth rates of the total data set did not show a clear agreement with one of the growth-ring patterns from the contemporary oak trees. A division into two distinct classes, with the series holding less than 50 growth rings separated from the 
(a)

(c)
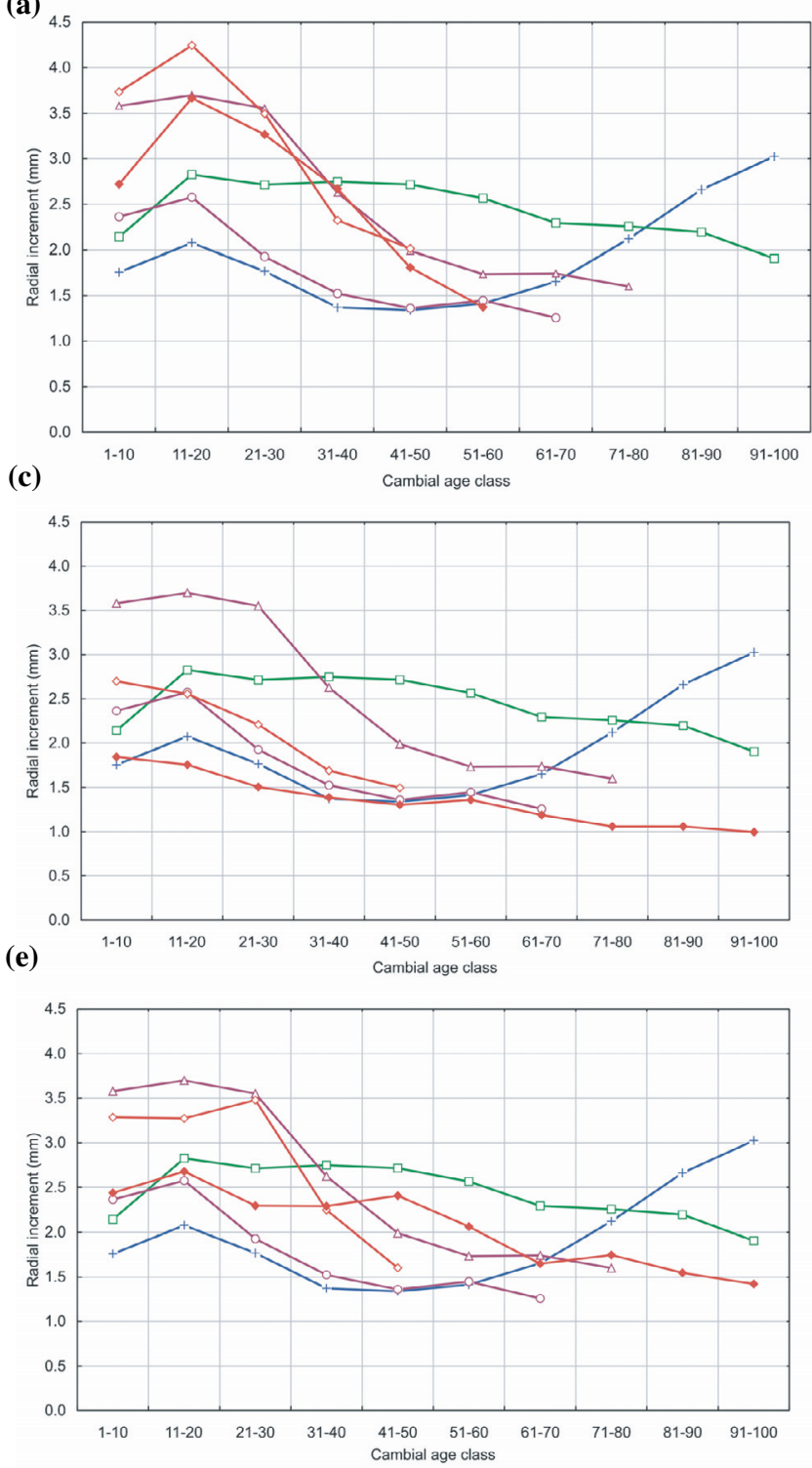

(b)

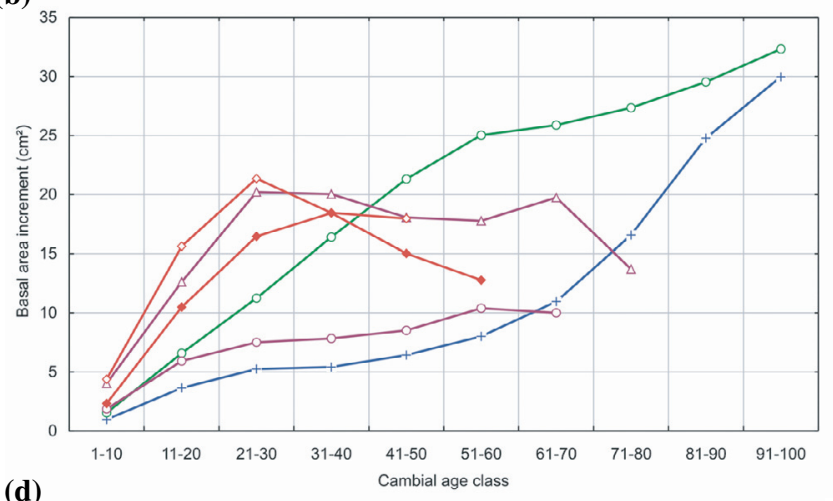

(d)
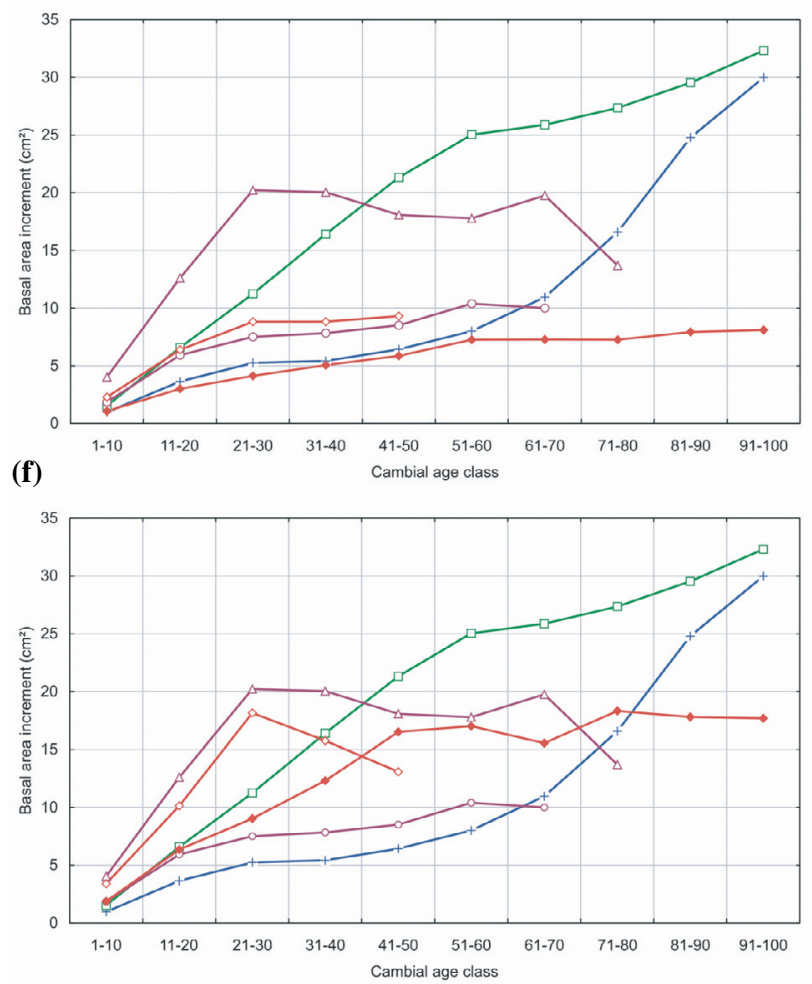

Figure 3. Growth-patterns from archaeological sites ( $\diamond$ and $\diamond$ ): (a, b) Roman wells from Oudenburg (ca. 350-450 A.D.), (c, d) revetments and foundations sites near Ypres (ca. 1250-1300 A.D.), (e, f) construction timber from a medieval storage house (1358-1370 A.D.) at Lissewege. o coppice; $\triangle$ standards; $\square$ high forest; + natural regeneration of oak under pine.

longer ones, made the underlying differences more clear (Fig. 3c). The longer series display, after a short increase in growth rate, a slowly decreasing growth rate. This contrasts the shorter series, which have a high and increasing growth rate over the first 40 years, followed by a drastic decrease. When converting the ring-width series to BAI, similar discrepancies between the two groups of long and short series can be observed (Fig. 3f).

\section{DISCUSSION}

Stand density, beside soil fertility, soil texture, water capacity and climate, is often considered as the most important factor to influence the general level of the radial growth rate. The aver- age radial growth rate is therefore not suitable to provide more information on the forest structure than just stand density. Values of mean sensitivity and first-order autocorrelation are comparable to other oak stands in Europe (e.g. [20]). The highest mean sensitivity, recorded for the Mattemburg oaks, is probably induced by the more irregular nature of disturbances in an unmanaged pine stand with natural regeneration of oak. It can be concluded that the descriptive statistics mentioned have a limited potential for deducing information on stand structure and management.

The remarkable difference in growth rate between the long tree-ring series and the series with less than 50 rings suggests that the latter are not just the younger version of the former. Both groups probably experienced a different regeneration or 
had a completely different social status in the young developing forest.

Up to now, classification of historical and archaeological tree-ring series according to forest types is still based on assumptions. Nevertheless it is striking that confrontation of tree-ring patterns from archaeological sites with the data from contemporary oak trees reveals that highly similar and analogous growth trends are being observed. The growth rate can be expressed as ring width or as BAI. This allows further interpretation and the formulation of several hypotheses about former forest structure and management. Moreover, the method presented has the advantage that it not necessarily requires large data sets, unlike the method developed by Billamboz [4, 6]. The latter method, termed dendrotypology, classifies timber from archaeological sites using dendrological, dendrochronological and techno-morphological criteria. Single series with similar cambial age and growth trend are assembled into so-called local dendro-groups. This also leads to a more detailed insight in the age structure and dynamics of the stands where the wood was harvested.

Tree-ring series from the archaeological sites near Ypres and the medieval storage house at Lissewege exhibit a growth pattern that is more similar to oaks from a high forest stand or naturally regenerated oaks under close canopy. More specific, this statement holds for the longer tree-ring series, i.e. with more than 50 years (Figs. 3c and 3e). The ring widths for the different cambial classes display a slowly decreasing trend. Moreover, the increase in BAI is nearly linear for the first 40-60 years of growth (Figs. 3d and 3f). Both characteristics are similar to trees from high forest stands. On the other hand, short series from wood specimens of the Oudenburg and Ypres excavations display high similarities in growth trend with contemporary oaks from coppice stands, both in radial increment (Figs. 3a and $3 \mathrm{c}$ ) and in BAI (Figs. 3b and 3d). Short series from the medieval storage house at Lissewege (Fig. 3c) also display such a "coppice-like" trend. But for these wood specimens it is striking that the sudden decrease in growth rate only occurs after ca. 40 years of growth, what seems to be similar to the growth pattern from the widely spaced standards from a coppice-with-standards stand.

The overall growth rate of the Lissewege samples is also considerably high. So during the construction of the storage house (A.D. 1365-1370) fast-grown oaks were preferred. This also has some implications regarding the mechanical properties of the oak wood. Timber from fast-grown oaks is usually of the high-density type. For many ring-porous oak species, this type of wood often has better strength properties [33]. So the medieval constructors might have been aware of this, and preferred to use these fast-grown oaks. Indeed, wood density is an important feature that influences the overall quality of timber. For oak, the density is mainly controlled by the cambial age and the ring width [33]. The amount of the denser latewood will increase when the total ring width increases. According to recent research on oak trees from northern and central France, wood density hardly changes according to the type of forest management, site quality and geographic location, when cambial age and ring width are kept constant [13].

The implemented silvicultural management must have altered the available wood assortments over time [2]. The increasing popularity of short rotation systems as coppice and coppice-with-standards during Roman times and the Middle Ages will have resulted in timber of reduced dimensions. Trees from short rotation systems, as coppice, will usually be felled before they reach an age of 50-60 years. Such young oak trees have proportionally more juvenile wood. Also, young oak trees (less than 100 years old) have generally less sapwood rings compared to older (more than 100 years old) trees [15, 16, 18]. But, for the same growth rate, young trees have a relatively higher percentage of sapwood. In Flanders, a $1 \mathrm{~m}$ long log from a 50-year-old tree with an average growth rate of $2 \mathrm{~mm} /$ year has ca. $60 \%$ of sapwood where a similar log from a 150 -yearold tree has only ca. $30 \%$ of sapwood. Wood from a short rotation system thus yields a reduced amount of durable heartwood.

Tree-ring patterns that are likely to come from a coppice stand have been found on sites from the late Roman period (Oudenburg). Probably this practice goes back much earlier, as observed by Billamboz at Lake Constance/Bodensee [3, 5, 6]. Similar growth trends were observed in coppiced stands in southern England and Wales [10], what broadens the validity of this method outside the Flemish region where the studied tree-ring series were collected. Wood found on archaeological sites is not necessarily representative for the nearest wood resources at that time. Nevertheless it is striking that so much wood specimens, used for construction purposes, seem to be related to contemporary coppice stands. This is remarkable since a primary goal for coppice management must have been the supply of firewood. This could indicate that from the remaining forests, coppice stands were the most abundant and that medieval craftsmen were dependent on those sites for the provision of timber.

The considerations regarding the physical and mechanical properties of the local timber yield additional arguments for the import of high-quality timber of oak. It is well documented that ever since the 9-10 century vast amounts of high-quality timber with Baltic origin have been imported [17, 27]. This is also founded with dendrochronological evidence, especially with tree-ring series of wooden object from the 14 th to 16 th centuries $[7,8,30,31]$.

Past interventions in forest or woodland structure are still preserved in the growth-ring patterns of wood specimens found on archaeological sites. These growth patterns provide a useful tool in the reconstruction of past forest structure. It also provides more information and insight in the available wood assortments in former times. Although this study has focussed on European oak, recent observations on some cross-sections of ash (Fraxinus excelsior L.) from a coppice stand revealed a highly similar trend in their growth pattern compared to the oak specimens (Haneca, unpublished data). This opens future prospects for forest and woodland reconstruction, and stimulates further characterization of growth patterns that are related to a specific stand structure or silvicultural management system.

Acknowledgements: This study was undertaken within the framework of a research project funded by the Fund for Scientific Research - Flanders (Belgium). The authors owe their gratitude to Ilse Boeren, Maaike Minnaert, Bieke Lybeer, Liesbeth De Vetter and Robbie Goris for providing tree-ring data. Sofie Vanhoutte, Marc Dewilde, Anton Ervynck (Flemish Heritage Institute) and Benoît Delay were extremely helpful in the acquisition and preservation of the archaeological and historical wood specimens. 


\section{REFERENCES}

[1] Bechmann R., Trees and man: the forest in the Middle Ages (translated by K. Dunham), Paragon House, New York, 1990.

[2] Beeckman H., The impact of forest management on wood quality. The case of medieval oak, in: Van de Velde C., Beeckman H., Van Acker J., Verhaeghe F. (Eds.), Constructing Wooden Images: proceedings of the symposium on the organization of labour and working practices of late Gothic carved altarpieces in the Low Countries, Brussels 25-26 October 2002, VUB Press, Brussels, 2005, pp. 93-113.

[3] Billamboz A., Archéologie du bois et analyse des cernes, Le temps de la Préhistoire I, 1989, pp. 220-225.

[4] Billamboz A., Tree-ring analysis in archaeodendrological perspective. The structural timber form the south-western German lake dwellings, in: Bartholin T.S., Berglund B.E., Eckstein D., Schweingruber F.H. (Eds.), Tree rings and Environment, Proceedings of the International Dendrochronological Symposium, Ystad, Sweden, 3-9 September 1990 (LUNDQUA Report 34), Lund University, Lund, 1992, pp. 34-40.

[5] Billamboz A., Tree rings and pile-dwellings in Southern Germany: following in the footsteps of Bruno Huber, in: Dean J.S., Meko D.M., Swetnam T.W. (Eds.), Tree rings, Environment and Humanity, Proceedings of the International Conference, Tucson, Arizona, 17-21 May 1994, University of Arizona, Tucson, 1996, pp. 471-483.

[6] Billamboz A., Tree rings and wetland occupation in southwest Germany between 2000 and 500 BC: dendroarchaeology beyond dating in tribute to F.H. Schweingruber, Tree-Ring Research 59 (2003) 37-49.

[7] Bonde N., Dendrochronology and timber trade in northern Europe from the 15th to 17th century, in: Bartholin T.S., Berglund B.E., Eckstein D., Schweingruber F.H. (Eds.), Tree rings and Environment, Proceedings of the International Dendrochronological Symposium, Ystad, Sweden, 3-9 September 1990 (LUNDQUA Report 34), Lund University, Lund, 1992, pp. 53-55.

[8] Bonde N., Tyers I., Wazny T., Where does the timber come from? Dendrochronological evidence of the timber trade in Northern Europe, in: Sinclair A., Slater E., Gowlett J. (Eds.), Archaeological Sciences 1995. Oxbow Monograph 64, Oxbow books Ltd., Oxford, 1997, pp. 201-204.

[9] Buis J., Historia Forestis: Nederlands bosgeschiedenis, HES Uitgevers B.V., Utrecht, 1985.

[10] Crockford K.J., Savill P.S., Preliminary yield tables for oak coppice, Forestry 64 (1991) 29-49.

[11] Fritts H.C., Tree-rings and Climate, Academic Press, London, 1976.

[12] Fritts H.C., Swetnam T.W., Dendroecology: a tool for evaluating variations in past and present forest environments, Adv. Ecol. Res. 19 (1989) 111-188.

[13] Guilley E., Herve J.C., Nepveu G., The influence of site quality, silviculture and region on wood density mixed model in Quercus petraea Liebl., For. Ecol. Manage. 189 (2004) 111-121.

[14] Haneca K., Boeren I., Van Acker J., Beeckman H., Dendrochronology in suboptimal conditions: tree rings from medieval oak from Flanders (Belgium) as dating tools and archives of past forest management, Veg. Hist. Archaeobot., in press (2005), DOI: 10.1007/ s00334-005-0022-x.
[15] Hillam J., Morgan R.A., Tyers I., Sapwood estimates and the dating of short ring sequences, BAR International Series 333 (1987) 165185.

[16] Hollstein E., Mitteleuropäische Eichenchronologie, Trierer dendrochronologische Forschungen zur Archäologie und Kunstgeschichte, Trier Grabungen und Forschungen 11, Verlag Phillipp von Zabern, Mainz am Rhein, 1980.

[17] Houbrechts D., Pieters M., Tonnen uit Raversijde (Oostende, prov. West-Vlaanderen): een goed gedateerd verhaal over water- en andere putten, Archeologie in Vlaanderen V (1996) 225-261.

[18] Hughes M.K., Milsom S.J., Leggett P.A., Sapwood estimates in the interpretation of tree-ring dates, J. Archaeol. Sci. 8 (1981) 381-390.

[19] Kollman F.F.P., Côté W.A. Jr., Principles of Wood Science and Technology I: Solid wood, Springer-Verlag, Heidelberg, 1968.

[20] Lebourgeois F., Guillaume C., Ducos Y., Climate-tree-growth relationships of Quercus petraea Mill. stand in the Forest of Bercé ("Futaie des Clos", Sarthe, France), Ann. For. Sci. 61 (2004) 361372.

[21] Rackham O., Ancient woodland: its history, vegetation and uses in England, Castlepoint Press, Dalbeattie, 2003.

[22] Rijsdijk J.F., Laming P.B., Physical and related properties of 145 timbers. Information for practice, Kluwer Academic Publishers, Dordrecht, 1994.

[23] Rinn F., TSAP-Win User Reference (version 0.53), RinnTech, Heidelberg, 2003.

[24] Rozas V., Dendrochronology of pedunculate oak (Quercus robur L.) in an old growth pollarded woodland in northern Spain: establishment patterns and the management history, Ann. For. Sci. 62 (2005) 13-22.

[25] Schweingruber F.H., Der Jahrring. Standort, Methodik, Zeit und Klima in der Dendrochronologie, Paul Haupt, Bern, 1983.

[26] Tack G., van den Bremt P., Hermy M., Bossen van Vlaanderen. Een historische ecologie, Davidsfonds, Leuven, 1993.

[27] Tossavainen J., Dutch forest products' trade in the Baltic from the Late Middle Ages to the peace of Munster in 1648, Ph.D. dissertation, University of Jyväskylä, Jyväskylä, 1994.

[28] Tsoumis G., Science and technology of wood: structure, properties, utilization, Van Nostrand Reinhold, New York, 1991.

[29] Vera F.W.M., Grazing ecology and forest history, CABI Publishing, Wallingford, 2000.

[30] Wazny T., The origin, assortments and transport of Baltic timber, in: Van de Velde C., Beeckman H., Van Acker J., Verhaeghe F. (Eds.), Constructing Wooden Images: proceedings of the symposium on the organization of labour and working practices of late Gothic carved altarpieces in the Low Countries, Brussels, 25-26 October 2002, VUB Press, Brussels, 2005, pp. 115-126.

[31] Wazny T., Eckstein D., Der Holzhandel von Danzig/Gdansk - Geschichte, Umfang und Reichweite, Holz Roh- Werkst. 45 (1987) 509-513.

[32] Wrobel S., Eckstein D., Die Bauholzversorgung in Lübeck vom 12. - 16. Jahrhundert, in: Gläser M. (Ed.), Archäologie des Mittelalters un Bauforschung im Hanseraum. Eine Festschrift für Günter P. Fehring, Konrad Reich Verlag, Rostock, 1993, pp. 531-535.

[33] Zhang S.Y., Effect of growth rate on wood specific gravity and selected mechanical properties in individual species from distinct wood categories, Wood Sci. Technol. 29 (1995) 451-465. 